Збірник наукових праць Українського державного університету залізничного транспорту

УДК 528.4:332.3

ВИЗНАЧЕННЯ МІСТОБУДІВНИХ ФАКТОРІВ, ЯКІ ВПЛИВАЮТЬ НА ВИКОРИСТАННЯ ЗЕМЕЛЬ МІСТ

Д-р екон. наук К. А. Мамонов, д-р техн. наук К. О. Метешкін, М. О. Грек (ХНУМГ ім. О. М. Бекетова)

ОПРЕДЕЛЕНИЕ ГРАДОСТРОИТЕЛЬНЫХ ФАКТОРОВ, ВЛИЯЮЩИХ НА ИСПОЛЬЗОВАНИЕ ЗЕМЕЛЬ ГОРОДОВ

Д-р экон. наук К. А. Мамонов, д-р техн. наук К. А. Метешкин, М. О. Грек (ХНУГХ им. А. Н. Бекетова)

\title{
DEFINITIONS URBAN DEVELOPMENT FACTORS THAT AFFECT THE USE OF CITY LANDS
}

Dr. sc. sciences K. A. Mamonov, dr. sc. Sciences K. O. Meteshkin, M. O. Grek

Наведено основні напрями та показники визначення містобудівних факторів, які впливають на використання земель міст. Визначені містобудівні фактори дають змогу побудувати систему управління земельними відносинами міст. Особливе значення мають визначені групи зачікавлених осіб, щчо впливають на містобудівну діяльність і обумовлюють рівень використання земель. У результаті дослідження визначені перспективні напрями подальших досліджень у контексті формування стейкхолдерно-орієнтованого підходу до оцінки впливу містобудівних факторів на використання земель міст.

Ключові слова: містобудівні фактори, використання земель, стейкхолдери, земельні відносини міст.

Представлены основные направления и показатели определения градостроительных факторов, влияющих на использование земель городов. Представленные градостроительные факторы позволяют построчть систему управления земельными отнотениями городов. Особое значение имеют группы заинтересованных лиц, которые влияют на 
градостроительную деятельность и обусловливают уровень использования земель. В результате исследования определены перспективные направления дальнейших исследований в контексте формирования стейкхолдерно-ориентированного подхода к оценке влияния градостроительных факторов на использование земель городов.

Ключевые слова: градострочтельные факторы, использование земель, стейкхолдеры, земельные отношения городов.

We represent the main areas and urban indicators determining factors that influence land use cities. Designated urban factors can build a system of land relations cities. Of particular importance are identified stakeholder groups that affect urban activities and determine the level of land use. The study identified promising areas for further research in the context of steykholdernobased approach to assess the impact of factors on urban land use cities.

Keywords: urban factors of land use stakeholders, land relations cities.

Вступ. Сучасні напрями розвитку міст, неоднозначні тенденції їх функціонування потребують переосмислення підходів до визначення містобудівних факторів у системі земельних відносин, їх впливу на використання земель мегаполіса, ураховуючи особливості взаємовідносин між різними групами зацікавлених осіб.

Аналіз останніх досліджень i публікацій. Над вирішенням проблем визначення містобудівних факторів, використання земель міст працювали такі науковці, як С. Кисіль [1], О. Лихогруд [2], Ю. Палеха [3], О. Панухник [4], І. Перович [5], В. Сидоренко [6], Р. Тімченко [7], А. Третяк [8] та ін.

Визначення мети та задачі дослідження. Метою статті $€$ визначення містобудівних факторів, які впливають на використання земель міст.

Для досягнення визначеної мети вирішуються такі завдання:

- проаналізувати підходи до визначення містобудівних факторів, які впливають на використання земель міст;

- сформувати групи містобудівних факторів, які впливають на використання земель міст.

Основна частина дослідження. В існуючих наукових розробках відсутні єдині підходи до визначення містобудівних факторів, які впливають на використання земель міст. Так, Ю. Палеха серед факторів, що впливають на розвиток ринку землі, виділяє стабільність містобудівної політики органів місцевого самоврядування, що визначається сталим урбаністичним розвитком $[3$, с. 26]. Отже, цей автор фокусує увагу на визначенні напрямів містобудівного розвитку у контексті реалізації містобудівної політики органами місцевого самоврядування. Поряд 3 цим залишаються поза увагою напрями та особливості використання земель у системі функціонування міських агломерацій.

У цьому аспекті заслуговує на увагу точка зору I. Перовича та Л. Винарчика, які визначають важливим містобудівним фактором, що впливає на використання земель, функціональне зонування як розподіл території міста за характером переважного використання, тобто за типом функціонального призначення тієі чи іншої території [5]. Представником цього підходу, по праву, можна вважати О. Лихогруда, який у системі показників, що впливають на вартість майна, виділяє такі містобудівні фактори:

вид використання земельної ділянки щодо зонування територій;

обмеження;

обтяження;

привабливість земельної ділянки;

планування;

якість об'єктів та конструктивних елементів [2].

Наведений підхід дає змогу визначити важливий містобудівний фактор - 
функціональне призначення земель для забезпечення розвитку міст, і враховувати його для оцінки впливу містобудівних факторів на використання земель.

Д. Ільченко у системі факторів, що впливають на вибір порушеної території при формуванні комплексної зеленої зони міста виділяє такі містобудівні параметри:

- розміщення порушеної території у планувальній структурі міста (центр, середина, периферія);

- наближеність до центру, до місць відпочинку та прикладення праці, що позначить радіус доступності цієї території;

- забезпеченість (чи можливість забезпечення) інженерними комунікаціями, у тому числі транспорт та ін.;

- приналежність до функціональної зони міста (сельбищної, промислової, комунально-складської, рекреаційної тощо) та взаємозв'язок 3 прилеглими чи навколишніми зонами;

- наявність системи внутрішніх взаємозв'язків структурних елементів зеленої зони [9]. Таким чином, автор визначає групу містобудівних факторів, що впливають на використання територій міст, які мають порушений характер.

Відповідно до Закону України "Про регулювання містобудівної діяльності”, враховуючи рівень їх використання, визначаємо такі містобудівні фактори:

- Генеральна схема планування територій України;

- схеми планування окремих частин території України;

- схеми планування території Автономної Республіки Крим, областей та районів;

- генеральні плани населених пунктів, плани зонування територій і детальні плани території;

- планувально-просторова організація забудови;

- червоні лінії та лінії регулювання забудови території;

- функціональне призначення, режим та параметри забудови однієї чи декількох земельних ділянок, розподіл територій згідно 3 будівельними нормами, державними стандартами і правилами;

- містобудівні умови та обмеження (у разі відсутності плану зонування території) або уточнення містобудівних умов та обмежень згідно із планом зонування території;

- потреба в підприємствах і закладах обслуговування населення, місце їх розташування;

- доцільність, обсяги, послідовність реконструкції забудови;

- черговість та обсяги інженерної підготовки території;

- система інженерних мереж;

- організація транспортного i пішохідного руху;

- комплексний благоустрій та озеленення, потребу у формуванні екомережі;

- межі прибережних захисних смуг i пляжних зон водних об'єктів (у разі відсутності плану зонування території) [10].

Отже, у запропонованому нормативно-правовому документі визначення містобудівних факторів здійснюється відповідно до рівнів використання земель, що дає змогу приймати рішення, враховуючи напрями та особливості формування й здійснення земельних відносин, а також взаємодії між різними групами зацікавлених осіб.

Визначено такі містобудівні фактори, що впливають на використання земель міст на різних рівнях їх використання:

на державному - єдина цифрова топографічна основа території країни, державний кордон та межі адміністративно-територіальних одиниць, Генеральна схема планування території України, схема планування окремих частин території України, результати моніторингу стану розроблення генеральних планів, інформаційні ресурси галузевих кадастрів та інформаційних систем 3 питань використання територій, екологічного, інженерно-геологічного, сейсмічного, 
гідрогеологічного та іншого районування території країни, нормативно-правові акти у сфері містобудування, будівельні норми, державні стандарти і правила;

на регіональному - єдина цифрова топографічна основа території Автономної Республіки Крим і областей, межі адміністративно-територіальних одиниць, схема планування території Автономної Республіки Крим, областей та окремих частин території з об'єктами регіонального значення за межами населених пунктів, результати моніторингу стану розроблення генеральних планів населених пунктів, планів зонування територій (зонінгів) та детальних планів, інформаційні ресурси галузевих кадастрів та інформаційних систем 3 питань використання територій, екологічного, інженерно-геологічного, сейсмічного, гідрогеологічного та іншого районування території регіону, нормативно-правові акти у сфері містобудування, будівельні норми, державні стандарти і правила;

на міському - єдина цифрова топографічна основа території міста, межі населеного пункту та його адміністративнотериторіальних одиниць, Генеральний план міста, плани зонування (зонінги) територій, історико-архітектурний опорний план міста та детальні плани територій, межі кадастрових зон і кварталів, межі економіко-планувальних зон нормативної грошової оцінки земель міста, межі земельних ділянок, кадастрові номери земельних ділянок, угіддя земельних ділянок, цільове призначення земельних ділянок, вид функціонального використання земельних ділянок, нормативна грошова оцінка земельних ділянок, розподіл земель між власниками i користувачами, обмеження у використанні земельних ділянок, інженерно-транспортна інфраструктура, будинки i споруди, їx правовий режим, технічний стан, архітектурна та історико-культурна цінність, пам'ятки історико-культурної спадщини, реєстр назв вулиць та інших поіменованих об'єктів місцевості, реєстр адрес на території міста на підставі топографічних планів та рішень органів місцевого самоврядування про присвоєння та зміну адрес об'єктів на території міста, затверджені містобудівні програми, схеми та проекти розвитку інфраструктури, охорони пам'яток історії, культури i природи, озеленення, благоустрою та захисту території, інвестиційні програми та проекти на підставі відповідних рішень органів місцевого самоврядування про їх затвердження (погодження), інша містобудівна документація, матеріали проектної документації, дозволи (декларації) про будівництво, акти контрольних перевірок, документи на прийняття об'єктів в експлуатацію на підставі рішень про затвердження (погодження) відповідної документації, виданих дозволів на виконання будівельних робіт, зареєстрованих декларацій про готовність об'єкта до експлуатації та інших документів щодо об'єктів містобудування i будівництва, червоні лінії та лінії регулювання забудови, екологічні та інженерно-геологічні характеристики окремих територій i земельних ділянок, можливість провадження на них містобудівної діяльності 3 урахуванням планувальних обмежень на підставі відповідної містобудівної документації, даних екологічних, гідрометеорологічних, радіологічних, санітарно-гігієнічних та інших досліджень, нормативно-правові акти у сфері містобудування, будівельні норми, державні стандарти i правила на підставі рішень про їх затвердження відповідно до законодавства [11].

Отже, відповідно до наведеного нормативного документа, визначені містобудівні фактори характеризуються i пов'язуються із рівнем їх використання, що дає змогу визначити функціональне спрямування, застосовуючи інформаційноаналітичне, проектне та інше забезпечення. Такий підхід фокусує увагу на можливостях взаємодії між групами зацікавлених 
осіб, що функціонують на різних рівнях функціонування міських агломерацій.

Узагальнюючі існуючи теоретичні положення та практику проведення нормативної грошової оцінки населених пунктів [6, 12, 13], визначено містобудівні фактори, що впливають на використання земель міст (таблиця).

Таблиця

Містобудівні фактори, що впливають на використання земель міст, які визначені на основі напрямів нормативної грошової оцінки земель

\begin{tabular}{|c|l|}
\hline$№$ п/п & \multicolumn{1}{|c|}{ Містобудівний фактор } \\
\hline 1 & Доступність до концентрованих місць прикладання праці \\
\hline 2 & Доступність до місць масового відпочинку \\
\hline 3 & Забезпечення дитячими садками \\
\hline 4 & Забезпечення школами \\
\hline 5 & Престижність району для проживання \\
\hline 6 & Рівень водопостачання \\
\hline 7 & Рівень газопостачання \\
\hline 8 & Рівень електропостачання \\
\hline 9 & Рівень зашумленості \\
\hline 10 & Рівень чистоти повітря \\
\hline 11 & Доступність до зупинок суспільного транспорту \\
\hline 12 & Доступність до центру населеного пункту \\
\hline 13 & Забезпечення закладами торгівлі та громадського харчування \\
\hline 14 & Забезпечення закладами побутового обслуговування \\
\hline 15 & Забезпечення культурними та спортивними закладами \\
\hline 16 & Рівень підтоплення грунтовими водами \\
\hline 17 & Різноманітність місць прикладання праці \\
\hline 18 & Ускладнений рельєф \\
\hline 19 & Якість грунтів \\
\hline
\end{tabular}

С. Кисіль, характеризуючи напрями та особливості формування архітектури багатоповерхових автостоянок у містах, визначає такі містобудівні фактори:

- ущільнення забудови;

- особливості місцевої містобудівної ситуації;

- розвиток мережі автообслуговування [1].

Для визначення містобудівних факторів, що впливають на використання земель мегаполіса, заслуговує на увагу точка зору О. Панухника, яка характеризує відповідні рівні їх реалізації:

- плановий;

- організаційний;

- регулятивний;
- інформаційно-аналітичний;

- контрольний [4].

Такий підхід подано у роботах А. Третяка, який розглядає використання земель через призму правових, організаційних, економічних та інших заходів, що можуть впливати на містобудівний розвиток [8].

Наведений підхід дає змогу визначити вплив містобудівних факторів, ураховуючи рівні прийняття та реалізації управлінських рішень у сфері розвитку міст. Поряд 3 цим не визначені напрями та особливості впливу містобудівних факторів, їх перелік та характеристика відповідає існуючому нормативно-правовому забезпеченню. 
При визначенні впливу містобудівних факторів на використання земель міст особливе значення має характеристика напрямів, особливостей взаємодії між різними групами зацікавлених осіб (стейкхолдерів), що функціонують у сфері земельних відносин міст і впливають на містобудівний розвиток. $\mathrm{y}$ результаті узагальнення існуючих наукових розробок [14-16] визначено такі групи стейкхолдерів, які функціонують у сфері земельних відносин міст і впливають на містобудівну діяльність:

1-ша група: землевласники (юридичні і фізичні особи, що володіють земельними ділянками, визначають можливості реалізації містобудівних напрямів);

2-га група: землекористувачі (юридичні i фізичні особи, що використовують земельні ділянки, реалізують містобудівні напрями);

3-тя група: державні органи влади, що формують і реалізують земельні відносини, містобудівну політику на державному рівні, створюють нормативно-правове забезпечення;

4-та група: місцеві органи влади, що формують і реалізують земельні відносини, містобудівну політику на місцевому рівні, визначають нормативно-правове забезпечення, що входить до їх повноважень;

5-та група: територіальна громада, яка впливає і реалізує право власності на землю, забезпечує функціонування містобудівної сфери;

6-та група: фінансові установи (банківські та інші фінансові інституції, що забезпечують формування і кредитування фінансових ресурсів для потреб у земельній та містобудівній сферах міст);

7-ма група: інвестори, що здійснюють інвестування фінансових ресурсів у сферу використання земельних ресурсів міст та здійснення містобудівної діяльності;

8-ма група: громадські організації, які здійснюють вплив на формування й реалізацію земельної та містобудівної політики на недержавному рівні;

9-та група: організації, що реалізують інформаційну політику у сфері земельних відносин і містобудівної діяльності.

Висновки 3 дослідження, перспективи, подальший розвиток у даному напрямку. Отже, узагальнюючи вищенаведене, визначено групи містобудвіних факторів, що впливають на використання земель міст і застосовуються для оцінки.

1. Функціональні фактори, що визначають рівень використання територій міст для реалізації містобудівної діяльності: стабільність містобудівної політики, функціональне зонування; обмеження; обтяження; привабливість земельної ділянки; планування; якість об'єктів та конструктивних елементів; характеристики та структура територій; наявність системи внутрішніх взаємозв'язків структурних елементів зеленої зони; доцільність, обсяги, послідовність реконструкції забудови; комплексний благоустрій та озеленення, потреби у формуванні екомережі; розвиток території за видами та режимами переважного використання; спостереження небезпечних зон відвалів породи гірничодобувних підприємств, вугільних шахт, зон катастрофічного затоплення, затоплення паводковими водами, районів імовірних провалів та зсувів; обсяги та напрями сталих виробничих, трудових, культурнопобутових, рекреаційних взаємозв'язків із суміжними адміністративно-територіальними одиницями; характеристики житлового фонду, об'єктів обслуговування, промисловості, комунального господарства, вулично-дорожньої мережі, транспорту, будівельної бази; збалансованість місць прикладення праці і місць проживання; фактори, що визначають виробничу шкідливість, забезпеченість композиційних взаємозв'язків виробничої зони забудови 3 оточенням; умови сприймання різних ділянок промислової забудови у міському середовищі; 
забезпечення створення санітарно-захисних зон 3 включенням їх у єдину систему озеленення міста; інтенсивність використання територій; номенклатура елементів території комплексної зеленої зони міста, площа озеленених територій загального користування; допустима кількість одночасних відвідувачів території парків, лісопарків, лісів, зелених зон; архітектурно-просторові та архітектурнопланувальні рішення щодо територій для містобудівної діяльності; розміри територій зон відпочинку, зон різного функціонального призначення; відстані між зонами відпочинку і ділянками курортнорекреаційних установ, садівницьких товариств, автомобільних доріг загальної мережі і залізниць; рекреаційне навантаження на ландшафт зон відпочинку; розміщення курортно-рекреаційних установ на територіях 3 допустимими рівнями шуму; пристосування житлової забудови і громадських споруд, розміщених у курортній зоні; рекреаційний фонд для обслуговування тих, що лікуються й відпочивають; престижність району для проживання; ускладнений рельєф; якість грунтів; особливості містобудівної ситуації; природно-техногенні фактори, що впливають на містобудівний розвиток земель міст.

2. Інформаційні фактори: топографічні дані території країни на підставі державної топографічної карти України i планово-картографічної основи державного земельного кадастру; інформаційні ресурси галузевих кадастрів та інформаційних систем 3 питань використання територій, екологічного, інженерно-геологічного, сейсмічного, гідрогеологічного та іншого районування території; містобудівні програми, схеми та проекти розвитку інфраструктури, охорони пам'яток історії, культури і природи, озеленення, благоустрою та захисту території, інвестиційні програми та проекти на підставі відповідних рішень органів місцевого самоврядування, інша містобудівна інформація; екологічні та інженерно-геологічні, гідрологічні, транспортні характеристики окремих територій i земельних ділянок, можливість провадження на них містобудівної діяльності; стан проектної роботи, інженерної підготовки, інженерного обладнання; дані програм економічного i соціального розвитку; дані квартирного обліку за кількістю та складом родин; характеристика та економічні показники, що впливають на функціонування землекористувача; інвестиційна привабливість; планові показники; організаційні показники; регулятивні показники; інформаційно-аналітичні показники формування та розвитку земель; контрольні показники, показники, що визначають рівень формування та використання людського потенціалу міста.

3. Інфраструктурні фактори: потреба в підприємствах і закладах обслуговування населення, ефективність зв'язків промислових зон із сельбищними, рекреаційними та іншими територіями, забезпеченість залізничним транспортом, спільність інженерно-технічної інфраструктури, допоміжних виробництв, об'єктів соціально-побутового обслуговування, забезпеченість зв'язків 3 головними транспортними комунікаціями, які утворюють планувальний каркас міста, показники доступності до виробничих, інфраструктурних, соціальних, житлових та інших об'єктів, показники забезпечення інфраструктурними, громадськими, соціальними, торговельними, культурними, спортивними об'єктами, розвиток мережі автообслуговування, рівень зашумленості та чистоти повітря.

4. Фактори, що характеризують потенціал міста: виробничий та природноресурсний, оздоровчо-рекреаційний та туристичний, науково-дослідний, дослідноекспериментальний потенціал.

5. Рівень забудови територій.

Визначені фактори характеризують функціональне використання земель та 
об'єктів у сфері містобудівної діяльності, інформаційне та інфраструктурне забезпечення, потенційні можливості міст. Окремо виділено рівень забудови територій міських агломерацій. Запропоновані фактори дають змогу побудувати багаторівневу систему, що застосовується для оцінки впливу містобудівних факторів на використання земель міст та розроблення на цій основі заходів щодо зростання ефективності містобудівної діяльності.

Перспективами

подальшого дослідження $\epsilon$ розроблення стейкхолдерноорієнтованого підходу до оцінки впливу містобудівних факторів на використання земель, що дасть змогу розробити заходи підвищення ефективності земельних відносин міст.

\section{Список використаних джсерел}

1. Кисіль, С. С. Фактори, що впливають на формування архітектури багатоповерхових автостоянок у найзначніших містах [Електронний ресурс] / С. С. Кисіль // Архітектура будівель i споруд. - Режим доступу: http://er.knutd.com.ua/bitstream/123456789/ 2963/4/33.\%20Кисіль\%20С.С..pdf.

2. Лихогруд, О. М. Наукові підходи до визначення цінності земельних ресурсів містобудівних систем у ринкових умовах [Електронний ресурс] / О. М. Лихогруд. - Режим доступу: http://www.agrosvit.info/pdf/6_2016/13.pdf.

3. Палеха, Ю. М. Теорія і практика визначення вартості територій і оцінки земель населених пунктів України (економіко-географічне дослідження) [Текст]: автореф. дис... д-ра географ. наук: 11.00.02 - економічна та соціальна географія / Ю. М. Палеха. - К.: Національна академія наук України. Інститут географії, 2009. - 39 с.

4. Панухник, О. Містобудування в адміністративному районі: модернізаційноуправлінський аспект [Електронний ресурс] / О. Панухник. - Режим доступу: http://visnyk.academy.gov.ua/wp-content/uploads/2013/11/2013-2-16.pdf.

5. Перович, І. Л. Економіко-метаматичний підхід до оцінки землі населених пунктів на основі їх функціонально-планувальної структури [Електронний ресурс] / І. Л. Перович, Л. В. Винарчик // Геодезія, картографія і аерофотознімання. - 2013. - Вип. 78. - Режим доступу: https://www.google.com.ua/url?sa=t\&rct=j\&q=\&esrc=s\&source=web\&cd=2\&cad= rja\&uact $=8 \&$ ved=0ahUKEwjwp - .

6. Сидоренко, В. Д. Аналіз використання спеціалізованих програмних комплексів для вирішення питань грошової оцінки земель у Кривому Розі [Електронний ресурс] / В. Д. Сидоренко, А. Ю. Паламар. - Режим доступу: http://knu.edu.ua/Files/Gn96/25.pdf.

7. Процес управління територіальним розвитком міста [Електронний ресурс] / Р. О. Тімченко, Д. А. Крішко, Д. Ю. Пасічна [та ін.] // Вісник Криворізького національного университету. - 2012. - Вип. 30. - Режим доступу: http://knu.edu.ua/Files/V_30_2012/13.pdf.

8. Третяк, А. М. Землевпорядне проектування: теоретичні основи і територіальний землеустрій [Текст] / А. М. Третяк. - К. : Вища освіта, 2006. - 528 с.

9. Ільченко, Д. М. Фактори, що визначають вибір порушеної території для іiі функціонального використання при формуванні комплексної зеленої зони [Електронний pecypc] / Д. М. Ільченко. - Режим доступу: https://www.google.com.ua/url?sa=t\&rct=j\&q= \&esrc $=$ s\&source $=$ web $\& c d=6 \&$ cad=rja\&uact $=8 \& v e d=0$ ahUKEwjwp - .

10. Про регулювання містобудівної діяльності [Електронний ресурс]: закон України від 17 лютого 2011 р. № 3038-VI. - Режим доступу: http://zakon3.rada.gov.ua/laws/show/303817. 
11. Про містобудівний кадастр[Електронний ресурс]: постанова Кабінету Міністрів України від 25 травня 2011 р. № 559. - Режим доступу: http://zakon2.rada.gov.ua/laws/show/ 559-2011-П.

12. Про затвердження технічної документації по нормативній грошовій оцінці земель населеного пункту с. Зарванці Якушинецької сільської ради [Електронний ресурс]. - Режим доступу: http://yakush.silrada.org/2016/06/14/1278/.

13. Технічна документація з нормативної грошової оцінки земель (м. Нова Одеса, с. Криворіжжя, Нововоодеської міської ради, Новоодеського району Миколаївської області) [Електронний ресурс]. - Режим доступу: tp://www.novaodesa.mk.ua/regylyatorka/ groshova_nova_odesa.doc.

14. Jensen, M.C. (1976). Theory of the Firm: Managerial Behaviour, Agency Costs, and Ownership Structure // Journal of Financial Economics. 3. - P. 305-360.

15. Goodijk, R. (2003). Corporate governance and stakeholder management: the ING. CORPORATE OWNERSHIP\&CONTROL. Volume 1, Issue 1. 159-167.

16. Mitchell, R. K., Agle B. R., Wood D. J. (1997). Toward a Theory. Academy of Stakeholder Identification and Salience. 4. 853 - 886.

Мамонов Костянтин Анатолійович, д-р екон. наук, професор кафедри земельного адміністрування та геоінформаційних систем Харківського національного універститету міського господарства імені О. М. Бекетова. Тел.: (099) 291-73-54. E-mail: kostia_mamonov@mail.ru.

Метешкін Костянтин Олександрович, д-р техн. наук, професор кафедри земельного адміністрування та геоінформаційних систем Харківського національного універститету міського господарства імені О. М. Бекетова. Тел.: (098) 409-16-42. E-mail: kometeshkin@ @andex.ru.

Грек Марія Олександрівна, здобувач кафедри земельного адміністрування та геоінформаційних систем Харківського національного універститету міського господарства імені О. М. Бекетова. Тел.: (068) 889-45-32. E-mail: grekmariaa@gmail.com.

Mamonov Konstantin Anatolievich, doctor. Sc. science, professor of Department of Land Administration and GIS O. M. Beketov National University of Urban Economy in Kharkiv. Tel.: (099) 291-73-54.

E-mail: kostia_mamonov@mail.ru.

Meteshkin Konstantin Aleksandrovich, Sc. science, professor Department of Land Administration and GIS

O. M. Beketov National University of Urban Economy in Kharkiv. Tel.: (098) 409-16-42.

E-mail: kometeshkin@yandex.ru.

Grek Maria Aleksandrovna, graduate student of Department of Land Administration and GIS O. M. Beketov National University of Urban Economy in Kharkiv. Tel.: (068) 889 - 45 -32. E-mail: grekmariaa@ gmail.com.

Стаття прийнята 10.05.2017 p. 